DOI: 10.22630/EIOGZ.2014.105.5

Zeszyty Naukowe Szkoły Głównej Gospodarstwa Wiejskiego

Ekonomika i Organizacja Gospodarki Żywnościowej nr 105, 2014: 57-66

Sebastian Jarzębowski

Katedra Ekonomiki i Organizacji Przedsiębiorstw

Szkoła Główna Gospodarstwa Wiejskiego w Warszawie

\title{
Efektywność sektora przetwórstwa zbóż w kontekście organizacji łańcucha dostaw ${ }^{1}$
}

\section{Wstęp}

Celem badań było zidentyfikowanie ogniw łańcucha dostaw produktów zbożowych oraz przeprowadzenie analizy pod względem ich struktury. W artykule dokonano oceny efektywności przedsiębiorstw przetwórstwa zbóż, pełniących rolę integratora łańcucha, przy wykorzystaniu metody SFA (Stochastic Frontier Approach) oraz określono stopnień integracji w łańcuchu dostaw poszczególnych przedsiębiorstw, odwzorowujący siłę powiązań z partnerami handlowymi. Badaniami objęto przedsiębiorstwa prowadzące działalność w zakresie przetwórstwa zbóż. Okres analiz objął lata 2008-2011. Do próby badawczej włączono, w zależności od analizowanego roku, od 82 do 87 przedsiębiorstw.

Podstawą analiz były założenia dotyczące wymiany dóbr, wynikające z podziału pracy i specjalizacji. Jako że procesy te dokonują się w obszarze rynku (miejsca spotkań podaży dóbr i popytu na nie) analizę teoretycznego podłoża należy umiejscowić w teorii równowagi rynkowej, będącej niejako trzonem klasycznej teorii ekonomii. W toku rozważań nad tą teorią nasunęły się pytania odnośnie przyjętych w niej założeń. W teorii zakłada się bowiem, iż konsumenci posiadają pełne informacje o nabywanych dobrach, cenach i technologiach, co zasadniczo wyklucza istnienie asymetrii informacji. Dominuje przekonanie, iż wszyscy gracze doskonale dopasowują ilości dóbr, nie musząc w związku z tym

\footnotetext{
${ }^{1}$ Praca naukowa finansowana przez Narodowe Centrum Nauki ze środków na naukę w latach 2011-2013 jako projekt badawczy nr 2011/01/B/HS4/02612 „Stopień integracji w łańcuchu dostaw a efektywność przedsiębiorstw przetwórstwa rolno-spożywczego”.
} 
ponosić kosztów transakcyjnych, których istnienie ugruntowali w teorii Coase i Williamson [Coase 1937, 1960; Williamson 1990].

Ponieważ założenia teorii równowagi rynkowej nie są spełnione w rzeczywistości gospodarczej, trzeba liczyć się z występowaniem funkcjonalnych słabości rynku, do których zaliczyć można, po pierwsze, występowanie asymetrii informacji. Występowanie asymetrii informacji potwierdzone zostało m.in. w teorii procesów rynkowych (przedstawiciele szkoły austriackiej wskazali na nierówny podział wiedzy w społeczeństwie), w teorii rozwoju gospodarczego J.A. Schumpetera, w której wskazano na możliwości czerpania korzyści z przewagi posiadanej wiedzy oraz w teorii pana i sługi, w której bazuje się na problemach nawiązywania umów w warunkach istnienia asymetrii informacji. Po drugie, do słabości rynku zalicza się występowanie kosztów transakcyjnych, ugruntowane w teorii przez Coase'a i Williamsona, którzy wskazują na koszty transakcyjne jako skalę oceniania i wyboru rozwiązań organizacyjnych (form integracji). Po trzecie, słabością rynku jest występowanie praw własności, których alokacja ma wpływ na system gospodarczy, a ich redystrybucja i specyfikacja (ze względu na efekty zewnętrzne) wiąże się z ponoszeniem kosztów transakcyjnych. Po czwarte, słabością rynku wpływającą na możliwość nieosiągania stanu równowagi konkurencyjnej jest występowanie rosnących efektów skali. Na podstawie przeglądu literatury stwierdzić można, iż praktykami, które znajdują zastosowanie w kontekście przeciwdziałania funkcjonalnym słabościom rynku są m.in.: tworzenie powiązań z zewnętrznymi partnerami, włączanie do realizacji podwykonawstwa podmiotów zewnętrznych, różne formy integracji, współpracy, kooperacji i organizacji, zawieranie długoterminowych umów czy tworzenie symbiotycznych form partnerstwa.

\section{Struktura łańcucha dostaw przetworów zbożowych}

W celu wskazania miejsca przedsiębiorstw przetwórstwa zbóż w łańcuchu dostaw dokonano analizy jego struktury, uwzględniając poszczególne ogniwa.

Ważnym zagadnieniem $\mathrm{w}$ organizacji rynku jest powiązanie między poszczególnymi ogniwami łańcucha dostaw. W Polsce słabo rozwinięta jest integracja pionowa i pozioma poszczególnych ogniw branży zbożowej. Praktycznie nie rozwija się kontraktacja ziarna dla potrzeb różnych nabywców [Stańko 2007, s. 35]. Dodatkowo rynek zbóż charakteryzuje się znaczną sezonowością produkcji i podaży żywności. Wahania te mogą zostać ograniczone przez przemysł spożywczy, gdyż technologia przetwórstwa pozwala na wyprodukowanie artykułów o wysokim stopniu trwałości. Postęp techniczny i technologiczny w produkcji, przechowalnictwie i przetwórstwie żywności, w tym m.in. zbóż, również 
w znacznym stopniu przyczynia się do łagodzenia ekonomicznych i społecznych skutków sezonowości podaży żywności [Kowalski 2007, s. 32].

Kolejnym aspektem charakterystycznym dla łańcucha dostaw zbóż jest rozdrobnienie struktury produkcji wpływające bezpośrednio na wielkość partii surowca i możliwość zaopatrzenia kolejnych ogniw łańcucha dostaw. Odbiorca natomiast wymaga od swoich dostawców dużych, jednolitych pod względem jakościowym i dostarczonych na czas partii. Ze względu na specyficzną strukturę rolnictwa w Polsce oczywiste jest, iż tylko część z producentów zbóż jest w stanie spełnić te wymogi. W tym kontekście istotną rolę w dystrybucji ziarna może odgrywać zwiększanie siły rynkowej poszczególnych producentów poprzez włączanie się w struktury spółdzielcze lub tworzenie grup producenckich, ale również wzmocnienie znaczenia ogniwa skupu i handlu.

Łańcuch dostaw zbóż składa się z wielu ogniw połączonych ze sobą skomplikowanymi przepływami strumieni materiałów (rys. 1). Surowiec podlega kompleksowym procesom transformacji, a produkty zbożowe przetworzeniu w wysokim stopniu, co ma związek z długością łańcucha dostaw. Ziarno zbóż może być wykorzystywane do wytwarzania produktów zbożowo-mącznych lub pasz (a w ostatnich latach również na cele energetyczne). Z tego powodu można mówić o łańcuchu dostaw dla ziarna zbóż konsumpcyjnych i zbóż paszowych. Ocenie poddany został łańcuch dostaw zbóż, którego finalnym efektem moga być zarówno produkty zbożowo-mączne, jak i pasze.

Centralną pozycję w łańcuchu dostaw zbóż stanowi przetwórstwo pierwotne, tj. przemysł zbożowo-młynarski, który pełni rolę integrującą [Gołębiewski 2000, s. 19]. Silna pozycja tego ogniwa wynika z poziomu koncentracji i technologicznego wyposażenia oraz możliwości konfrontacji potrzeb i preferencji nabywców z możliwościami producentów surowca [Zalewski 1989]. Z jednej strony stwierdzić można, iż w wyniku wypadania z rynku małych przedsiębiorstw i wewnętrznego wzrostu dużych firm, produkcja roczna na jedno przedsiębiorstwo stale rośnie. Równolegle do tego mają miejsce przejęcia i fuzje, tworzone są koncerny, przez co przyspieszana jest konsolidacja branży przetwórstwa zbożowo-młynarskiego w Polsce. Procesy te mają często miejsce przy udziale kapitału zagranicznego [Jarzębowski 2011].

\section{Ocena efektywności przedsiębiorstw przetwórstwa zbóż}

Wyłaniające się z modeli matematycznych równowagi ogólnej Walrasa, Walda czy Arrowa i Debreu przedsiębiorstwo może być opisane za pomocą matematycznej funkcji, zależnej od stosowanej technologii (bez innowacji) przekształcania nakładów w wyniki [Noga 2009]. W literaturze przyjmuje się, że 


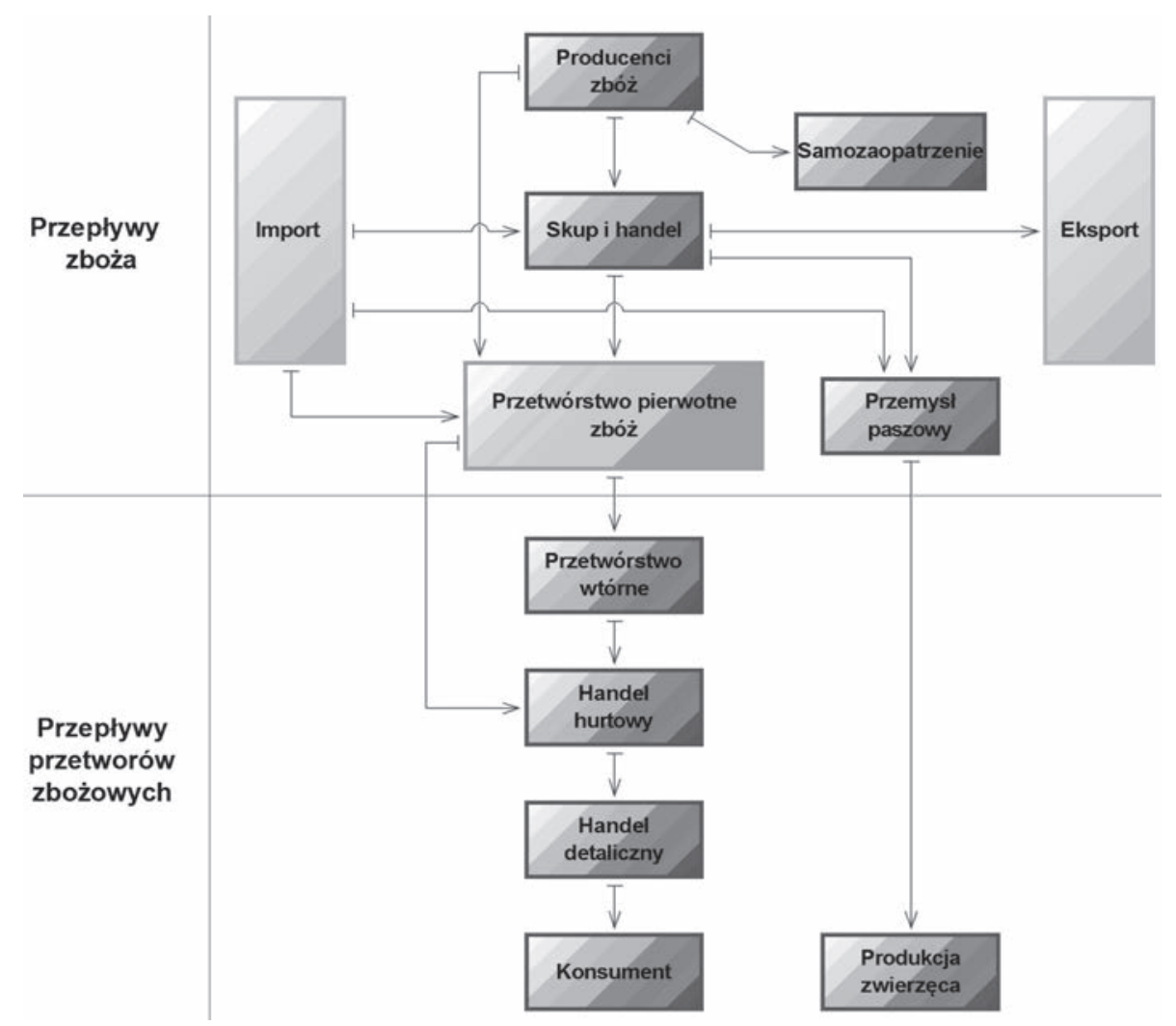

\section{Rysunek 1}

Struktura łańcucha dostaw zbóż i ich przetworów

Źródło: Opracowanie własne na podstawie Stańko i Bojańczyk 2000, s. 283.

funkcja produkcji ilustruje dostępne i efektywnie wykorzystywane techniki wytwarzania. Określa bowiem maksymalną wielkość: produktu (produkcji) możliwą do uzyskania przy danym poziomie zaangażowania czynnika (y) czy czynników produkcji $(x)$. Metodą oceny efektywności bazującą na funkcji produkcji jest stochastyczna metoda graniczna SFA (Stochastic Frontier Approach). W literaturze spotyka się również wykorzystanie narzędzi deterministycznych, których podłożem analitycznym nie jest funkcja produkcji, a zadanie optymalizacyjne (np. metoda DEA, Data Envelopment Analysis) ${ }^{2}$.

\footnotetext{
${ }^{2}$ Szerzej o modelach DEA w pracy Jarzębowski S., 2011: The efficiency of grain milling companies in Poland and in Germany - application of DEA method and Malmquist index, Universität Bonn-ILB Press, Bonn.
} 
Do oceny efektywności przedsiębiorstw zastosowano metodę SFA (Stochastic Frontier Approach). Zmienne wykorzystane do konstrukcji modelu to po stronie nakładów: aktywa trwałe $\left(x_{1}\right)$ i koszty operacyjne $\left(x_{2}\right)$, a po stronie efektów: przychody ze sprzedaży (y) wyrażone w PLN.

\section{Specyfikacja modelu}

W metodzie SFA wymagane jest wskazanie a priori formy funkcyjnej określającej zależność między nakładem/nakładami a efektem [Coelli i in. 2005]. W literaturze z zakresu efektywności wyznaczanej na podstawie funkcji produkcji można zaobserwować, iż funkcja typu Cobb-Douglasa jest jednym z najczęściej stosowanych w badaniach empirycznych narzędzi. Jak wskazują Piesse i Thirtle, adekwatność modelu Cobb-Douglasa testuje się względem mniej restrykcyjnej formy, jaką jest funkcja translogarytmiczna [Piesse i Thirtle 2000, s. 474]. Do oceny efektywności w sektorze przetwórstwa zbóż w latach 2008-2011 wykorzystano metodę SFA bazującą na ugruntowanych w teorii i praktyce badawczej funkcjach: Cobb-Douglasa i translogarytmicznej. Funkcję typu Cobb-Douglasa przedstawiono w równaniu (1), a funkcję translogarytmiczną w równaniu (2):

$$
\begin{aligned}
& \ln y_{i}=\beta_{0}+\sum_{j=1}^{k} \beta_{j} \ln x_{i j}+v_{i}-u_{i} \\
& \ln y_{i}=\beta_{0}+\sum_{j=1}^{k} \beta_{j} \ln x_{i j}+\frac{1}{2} \sum_{j=1}^{k} \sum_{l=1}^{k} \beta_{j l} \ln x_{i j} \ln x_{i l}+v_{i}-u_{i}
\end{aligned}
$$

gdzie:

$i$ - indeks oznaczający kolejny obiekt $i=1, \ldots, I$, gdzie $I$ to liczba obiektów w próbie,

$j-$ indeks oznaczający kolejny nakład $j=1, \ldots, 1$,

$k$ - liczba nakładów,

$y_{i}$ - efekt obiektu $i$,

$x_{i j}-\operatorname{nakład} j$ w obiekcie $i$,

$\beta$ - parametry do estymacji,

$v_{i}$ - zmienna losowa reprezentująca składnik losowy,

$u_{i}$ - dodatnia zmienna losowa powiązana z nieefektywnością (TE). 
Porównania postaci funkcyjnej dokonano na podstawie statystyki testu ilorazu wiarygodności (LR, likelihood ratio), która przyjmuje postać:

$$
L R=2\left[\ln L\left(\hat{\theta}_{R}\right)-\ln L\left(\hat{\theta}_{N}\right)\right]
$$

gdzie:

$\ln L\left(\hat{\theta}_{R}\right)$ - logarytm wartości największej wiarygodności modelu z restrykcjami, $\ln L\left(\hat{\theta}_{N}\right)$ - logarytm wartości największej wiarygodności modelu bez restrykcji.

\section{Tabela 1}

Weryfikacja hipotez odnośnie wyboru postaci funkcyjnej modelu

\begin{tabular}{|c|c|c|c|c|c|}
\hline Lata & $\operatorname{In} L\left(\hat{\theta}_{R}\right)$ & $\operatorname{In} L\left(\hat{\theta}_{N}\right)$ & $L R$ & Wynik $^{(1)}$ & Model \\
\hline 2008 & $-136,39$ & $-130,89$ & $10,99^{\star}$ & brak podstaw do odrzucenia $\mathrm{H}_{0}$ & Cobb-Douglasa \\
\hline 2009 & $-135,59$ & $-133,63$ & $3,92^{\star *}$ & brak podstaw do odrzucenia $\mathrm{H}_{0}$ & Cobb-Douglasa \\
\hline 2010 & $-120,68$ & $-119,85$ & $1,67^{\star *}$ & brak podstaw do odrzucenia $\mathrm{H}_{0}$ & Cobb-Douglasa \\
\hline 2011 & $-129,01$ & $-125,69$ & $6,64^{\star *}$ & brak podstaw do odrzucenia $\mathrm{H}_{0}$ & Cobb-Douglasa \\
\hline
\end{tabular}

(1) Wartość rozkładu $\chi 2$ dla $3^{3}$ stopni swobody przy poziomie istotności 0,05 (**) wyniosła 7,82 , z kolei przy poziomie istotności 0,1 (*) wynosiła 11,34. Jeśli $L R^{\star}<x 2(3)$, wówczas nie ma podstaw do odrzucenia hipotezy $\mathrm{H}_{0}$.

Źródło: Obliczenia własne.

Na podstawie wyników weryfikacji hipotez odnośnie wyboru postaci funkcyjnej stwierdzono, iż w każdym z sektorów we wszystkich analizowanych latach (przy poziomie istotności poniżej 0,1) właściwą postacią funkcyjną opisującą zależności między przyjętymi nakładami i efektami jest model typu Cobb-Douglasa. Efektywność oceniono na podstawie wartości ilorazu obserwowanego efektu (zmienna y; równanie 4) i maksymalnego do osiągnięcia efektu w środowisku (otoczeniu) charakteryzowanym przez $\exp \left(v_{i}\right)$, oznaczanego przez $y^{*}$ (wartość ta zakłada brak nieefektywności, czyli $u_{i}=0$ ), a więc wskaźnik efektywności można zapisać jako:

$$
T E_{i}=\frac{y_{i}}{y_{i}^{*}}=\frac{\exp \left(\beta_{0}+\sum_{j=1}^{k} \beta_{j} \ln x_{i j}+v_{i}-u_{i}\right)}{\exp \left(\beta_{0}+\sum_{j=1}^{k} \beta_{j} \ln x_{i j}+v_{i}\right)}=\exp \left(-u_{i}\right)
$$

\footnotetext{
${ }^{3}$ Liczba stopni swobody jest równa różnicy w liczbie parametrów w modelu bez restrykcji (tu model translogarytmiczny) i liczbie parametrów w modelu z restrykcjami (tu model typu Cobb-Douglasa).
} 
Granica efektywności wyznaczona została na podstawie oszacowania za pomocą metody maksymalnej wiarygodności ${ }^{4}$ parametrów funkcji produkcji przyjętej w metodzie SFA, tj. funkcji typu Cobb-Douglasa.

\section{Efektywność przedsiębiorstw a integracja łańcucha dostaw}

Uzyskane przy wykorzystaniu metody SFA wskaźniki efektywności przedsiębiorstw przetwórstwa zbóż zestawiono według ich wielkości (tab. 2).

\section{Tabela 2}

Średni wskaźnik efektywności wyznaczany przy zastosowaniu metody SFA według wielkości przedsiębiorstw w latach 2008-2011

\begin{tabular}{|l|c|c|c|c|}
\hline Rok/Wielkość przedsiębiorstw & 2008 & 2009 & 2010 & 2011 \\
\hline Mikro & 0,315 & 0,149 & 0,499 & 0,417 \\
\hline Małe & 0,301 & 0,182 & 0,527 & 0,460 \\
\hline Średnie & 0,317 & 0,174 & 0,523 & 0,491 \\
\hline Duże & 0,721 & 0,510 & 0,693 & 0,692 \\
\hline
\end{tabular}

Źródło: Obliczenia własne.

Na podstawie wyników zamieszczonych $\mathrm{w}$ tabeli 2 można zauważyć, iż w analizowanym sektorze przetwórstwa zbóż w każdym roku wraz ze zwiększaniem się wielkości przedsiębiorstw rośnie średni wskaźnik efektywności przez nie uzyskiwany ${ }^{5}$. W sektorze przetwórstwa zbóż przedsiębiorstwa najmniejsze uzyskały wskaźnik efektywności z przedziału od 0,14 do 0,49; średnia wartość wskaźnika efektywności w przedsiębiorstwach małych wyniosła od 0,18 do 0,52 , w przedsiębiorstwach średnich zawierała się w przedziale od 0,17 do 0,52 , a w przedsiębiorstwach dużych najniższa średnia wartość wskaźnika efektywności wyniosła 0,51, najwyższa natomiast - 0,72.

\footnotetext{
${ }^{4}$ Innymi metodami estymacji parametrów funkcji produkcji przy wyznaczaniu granicy efektywności jest metoda najmniejszych kwadratów i jej pochodne [Coelli i in. 2005].

${ }^{5}$ Ze względu na to, że w metodzie SFA wyznacza się relatywną efektywność, nie ma możliwości porównania wyników uzyskanych w poszczególnych modelach. W ramach metody SFA jednym z podejść, w którym istnieje możliwość oceny zmiany efektywności w latach jest stworzenie dynamicznego modelu oceny efektywności dla zbalansowanego panelu danych; por. A. Bezat 2011: Estimation of technical efficiency by application of the SFA method for panel data, Scientific Journal Warsaw University of Life Sciences - SGGW, Problems of World Agriculture, t. 11, nr 3, s. 5-13.
} 
W celu określenia stopnia integracji w łańcuchu dostaw, odwzorowującego siłę powiązań z partnerami handlowymi, poszczególnych grup przedsiębiorstw przetwórstwa zbóż zastosowano wskaźnik stopnia integracji SCIDM (Supply Chain Integration's Degree Measure) ${ }^{6}$.

\section{Tabela 3}

Wskaźnik stopnia integracji SCDIM według wielkości przedsiębiorstw w latach 2008-2011

\begin{tabular}{|l|r|r|r|r|}
\hline Rok/Wielkość przedsiębiorstw & 2008 & 2009 & 2010 & 2011 \\
\hline Mikro & 85,0 & 79,6 & 81,8 & 85,6 \\
\hline Małe & 102,1 & 98,2 & 120,0 & 110,9 \\
\hline Średnie & 106,2 & 98,7 & 124,8 & 116,8 \\
\hline Duże & 181,0 & 165,0 & 177,0 & 167,0 \\
\hline
\end{tabular}

Źródło: Obliczenia własne.

Na podstawie tabeli 3 można zauważyć, iż w każdym z analizowanych lat, tj. 2008-2011 wraz ze zwiększaniem się wielkości przedsiębiorstw rośnie średni wskaźnik stopnia integracji SCIDM.

\section{Podsumowanie}

Podstawą analiz podjętych w ramach artykułu były założenia odnośnie wymiany dóbr, dokonujące się w obszarze rynku (miejsca spotkań podaży dóbr i popytu na nie). Ponieważ założenia teorii równowagi rynkowej nie są spełnione w rzeczywistości gospodarczej, należy liczyć się z występowaniem funkcjonalnych słabości rynku, do których zaliczyć można występowanie asymetrii informacji, kosztów transakcyjnych, występowanie praw własności i rosnących efektów skali. Praktykami, które znajdują zastosowanie w kontekście przeciwdziałania funkcjonalnym słabościom rynku są m.in.: tworzenie powiązań z zewnętrznymi partnerami, włączanie do realizacji podwykonawstwa podmiotów zewnętrznych, różne formy integracji, współpracy, kooperacji i organizacji, zawieranie długoterminowych umów, symbiotyczne formy partnerstwa. W artykule zidentyfikowano ogniwa łańcucha dostaw produktów zbożowych oraz

\footnotetext{
${ }^{6}$ Ze względu na ograniczenia objętościowe artykułu przedstawiono syntetyczne wyniki. Szczegółowy opis wskaźnika stopnia integracji SCIDM został zamieszczony w S. Jarzębowski 2013: Integracja łańcucha dostaw jako element kształtowania efektywności sektora przetwórstwa rolno-spożywczego, Wydawnictwo SGGW, Warszawa.
} 
przeanalizowano je pod względem struktury w celu wskazania miejsca analizowanych przedsiębiorstw w łańcuchu dostaw.

W części analitycznej artykułu dokonano oceny efektywności przedsiębiorstw przetwórstwa zbóż przy wykorzystaniu metody SFA (Stochastic Frontier Approach) oraz określono stopień integracji w łańcuchu dostaw, odwzorowujący siłę powiązań z partnerami handlowymi poszczególnych przedsiębiorstw. Na podstawie przeprowadzonej analizy stwierdzono, iż przedsiębiorstwa najbardziej efektywne charakteryzują się najwyższym stopniem integracji w łańcuchu dostaw, są to równocześnie przedsiębiorstwa największe. Przedsiębiorstwa małe i średnie znacznie zwiększyły stopień integracji po 2009 roku. Przedsiębiorstwa mikro zachowały niski stopień integracji w badanym okresie. Oznacza to, iż głównie duże przedsiębiorstwa z branży przetwórstwa zbóż podejmują działania polegające na tworzeniu powiązań z zewnętrznymi partnerami, mające na celu przeciwdziałanie funkcjonalnym słabościom rynku, osiagając przy tym wyższy poziom efektywności.

\section{Literatura}

BEZAT A. 2011: Estimation of technical efficiency by application of the SFA method for panel data, Scientific Journal Warsaw University of Life Sciences - SGGW, Problems of World Agriculture 2011, t. 11, nr 3, s. 5-13.

COASE R.H. 1937: The Nature of the Firm, Economica New Series, nr 4, s. 386-405.

COASE R.H. 1960: The Problem of Social Cost, Journal of Law and Economics, nr 3, S. $1-44$.

COELLI T.J., RAO D.S.P., O`DONNELL CH.J., BATTESE G.E. 2005: An introduction to efficiency and productivity analysis, 2. Edition, Springer, New York.

GOŁĘBIEWSKI J. 2000: Rynek zbóż w Polsce w okresie przemian systemowych, Wyd. SGGW, Warszawa.

JARZĘBOWSKI S. 2011: The efficiency of grain milling companies in Poland and in Germany - application of DEA method and Malmquist index, Universität Bonn-ILB Press, Bonn.

JARZĘBOWSKI S. 2013: Integracja łańcucha dostaw jako element ksztaltowania efektywności sektora przetwórstwa rolno-spożywczego, Wydawnictwo SGGW, Warszawa.

KOWALSKI A. 2007: Istota i funkcjonowanie rynku żywnościowego, [w:] Rembisz W., Idzik M. (red.), Rynek rolny w ujęciu funkcjonalnym. Wyd. Wyższa Szkoła Finansów i Zarządzania, Wyd. IERiGŻ-PIB, Warszawa.

NOGA A. 2009: Teorie przedsiębiorstw, Polskie Wydawnictwo Ekonomiczne, Warszawa.

PIESSE J., THIRTLE C. 2000: A Stochastic Frontier Approach to Firm Level Efficiency, Technological Change and Productivity during the Early Transition in Hungary, Journal of Comparative Economics, t. 28, nr 3, s. 473-501.

STAŃKO S. 2007: Tendencje na rynku zbóż, [w:] Klepacki B. (red.), Czy grozi Polsce kryzys zbożowy (w świetle pozarolniczego wykorzystania ziarna), Wyd. Wieś Jutra, Warszawa, s. 30-39. 
STAŃKO S., BOJAŃCZYK E. 2000: Rynek zbożowy, [w:] Majweski E., Dalton G. (red.), Strategiczne opcje dla polskiego sektora agrobiznesu w świetle analiz ekonomicznych, SGGW Centrum Naukowo-Wdrożeniowe, Warszawa.

WILLIAMSON O.E. 1990a (red.): Organization theory: From Chester Barnard to present and beyond, Oxford Press University, New York.

ZALEWSKI A. 1989: Problemy gospodarki żywnościowej w Polsce, Wyd. PWN, Warszawa.

\section{Efficiency of grain processing sector in terms of supply chain organization}

\section{Abstract}

Within the framework of the paper, the elements of supply chain of grain products were identified and analyzed in terms of structure. The assessment of the efficiency of grain processing enterprises, which are the integrator of the chain, using the SFA method (Stochastic Frontier Approach) was carried out. The supply chain integration degree, showing the strength of relationships of individual enterprises with business partners, was identified. 